through private subscription, partly through subsidies of the German Government. Among the travellers I may name ( 1 ) Dr. M. Buchner, who, starting from San Paolo de Loanda in an easterly direction, may have already reached the large lakes of the Upper Nile or the Upper Congo; (2) Dr. Oscar Lenz, who is on the way from Marocco to Timbuctoo, whence he will proceed to Senegambia; (3) a large expedition, comprising Dr. Böhm, von Schüler, I)e Kayser, \&c., which will establish a station near the Tanganyika lake, in connection with the stations of the International Association; (4) Gerhard Rollfs and Dr. Stecker will soon proceed to Abyssinia, and thence the latter through the Gallas country to the sea-coast; (5) Dr. Pogge, together with several other travellers, will shortly start from San Páolo đé Loanda for the interior, to establish a German station in the neighbourhood of the Muate Janvo, about in the middle of the Continent ; finally (6) Herr Flegel will follow the course of the Binué upwards, and explore the sources of that river." The German African Society has certainly developed under the presidency of Dr. Nachtigall a very unusual activity, and it is only to be hoped that these great efforts in the interest of the exploration of Africa may have good results.

THE French journal L'Exploration has much improved recently; its reports of geographical societies in all parts of the world are specially valuable. Its value would be still greater if it would aim at greater originality, and display more enterprise in the collection of news. It rarely gives any authorities for its numerous notes, thus minimising their value; and too much space is devoted to the translation of long articles from the Times and other popular sources. This may perhaps render it interesting to the general French public, but greatly detracts from its scientific and international value. However, if it goes on improving in the future as it has done during the last few months, it will ultimately become a really valuable geographical organ.

THE new number of Le Globe contains a useful account of geographical work in Central Asia, in $\times 878-1879$, contributed by M. Vennikof.

IN view of the present importance of Asterabad, Her Majesty's Consul opportunely gives a brief geographical description of the province. It is situated in the sonth-east corner of the Caspian Sea ; its inhabitants do not exceed $45, \infty 00$, and the town can only boast of 8,000 souls. It is bounded on the soutb by the high range of mountains which separate the Caspian provinces from the other parts of Persia; on the north it is bounded by the Atrek as far as Chat, at the confluence of that river and the Sombar, while beyond that point the position of the boundary is doubtful. 'The west is bounded by the Caspian Sea and the province of Mazanderan, and in the east it adjoins the province of Meshed. Gez, Molla Kellé and Gumush Teppé are the only ports in use. The province is well-wooded, and is watered by numerous mountain streams. Its inhabitants belong to the Kajar tribe, of which the Shah is the personal head. The fertility of the soil is great, and the timber in the forests is magnificent, but unfortunately there are no roads worthy of the name.

M. Bouthillife De Benumont, the President of the Geneva Geographical Society, has just published a pamphlet entilled Choix d'un Méridie'n Initial Uniquc.

THE Colonies and India publishes an interesting summary of a plan which Mr. G. J. Morrison, the engincer of the short-lived Woosung railway, has sketched for the restoration of the Grand Canal, which at present is usually impassablc in places. The essential point in his scheme is the substitution of proper locks for the wasteful sluices now in use, with of course more extensive works at the crossing of the Yellow River.

Tru same paper states that the Iegislative Assembly of the Transvaal has before it a measure providing for a trigonometrical and geological survey of the country, in the course of which it is expected that abundant mineral wealth will be proved to exist in the colony.

ON July 13 , at the end of the French legislative session, the Minister of Marine and the Colonies presented to the Lower House a credit of $\mathrm{I}, 300,000$ francs for establishing fortified pasts from Medina on the Senegal to Bafoulabe on the Niger, on the route which will be followed by the projected railway for connecting these two large rivers. It includes also several other items connected with the same scheme. It was adopted on the same day and voted by the Senate on the 15 th, so that the first step may be said to have been taken for the establishment of the connecting link between Algiers and St. Louis, via Timbuctoo.

\section{PLANTS OF THE COAL-MEASURES}

M RENAULT has recently published a memoir, in which he reproduces the views of $M$. Brongniart resnecting the relations which the Lepidodendra bear to the Sigillaria, still insisting that the former are cryptogamic Lycopods, whilst the latter arc exogenous Gymnosperms. In endeavouring to establish this position, the French palæo-botanist concludes that if the exogenous Diploxyloid stems (i.e., Sigillarian ones) are but matured states of some Lepidodendra, every Sigillarian type of organisation ought to be found in a young or Lepidodendroid form, because, he contends, the type of the central organisation, once established, undergoes no further change with advancing agc. In support of his position he affirms that there are three such Sigillarian types, viz. (I) Sigillaria vascularis, (2) Diploxyloid stems, (3) Favularia and Leiodermaria. At present he contends that only the second of these forms has been discovered in Lepidodendron Harcourtii. IIe further believes that there are three types of Lepidodendron known, represented by (r) $L$. rhodumense, with a solid central vascular axis, in which the vessels are not intermingled with medullary cells; $(2)$ by $L$. Harcourtii, in which the vascular axis is a cylinder surrounding a cellular medulla; and (3) an undescribed plant, which he names $L$. Futicri, in which the vascular cylinder is broken up into detached bundles of vessels.

The author of the present paper considers that the above conclusions are not in accordance with the facts, and he proceeds to give his reasons for this conclusion by demonstrating that we certainly have two of the three supposed Sigillarian types represented in a young or Lepidodendroid state : the first by Lepidodendron vasculare of Binney, and the second by L. IIarcourtii, whilst, judging from M. Renault's own description, the $L$. Futieri represents the third type. On the other hand, the author believes that of M. Renault's three Lepidodendroid types the first is only a young state of the second, as illustrated by the development of the Burntisland and Arran Lepidodendra described in previous memoirs, whilst the able Frenchman appears not to have been acquainted with the existence of the very characteristic type of the $L$. vasculare of Binney.

The author gives the series of facts upon which his opinions arc based by tracing the history of the development, first, of Lcpidodendron Sclaginoides, the $L$. vasrulure of Binney, and second, of L. ITarcourtii.

Commencing with the declaration that the Lepidodendron vasculare of Mr. Binney is but the young state of the Sigillaria vascularis of the same author, he proceeds to show the successive stages by which the vasculo-cellular medullary axis of the former becomes not only inclosed within the cxngenous cylinder of the latter, but that this cylinder ultimately develops into a very conspicuous example of the Diploxyloid form of stem. The growth of the exogenous cylinder begins at one point of the periphery of the vasculo-medullary axis, from which point it extends both laterally and radially. The exogenous growth thus first appears in the transverse section of the l.epidodendroid twig as a small crescent, thickcst at its centre, but whose two horns creep gradually round the medullary axis, its constituent vascular wedges also growing radially as the lateral growth advances, until at length the exogenous zone forms a complete ring, inclosing the vasculo-medullary axis, in which state it becomes the Sigillaria vascularis of $\mathrm{Mr}$. Binney and $\mathrm{M}$. Renault. The various stages of this growth are represented in the plates, in addition to which a section is described and figured of a branch about to dichotomise, in which process the vasculo-medullary axis has divided into two equal halves, one being destined for each branch. One of these halves of the vasculo-medullary axi displays, with the utmost distinctnese, the characteristic crescentic commencement of an exogenous zone, whilst the other half retains its primary non-exogenous state. The latter condition thus belongs to the Lepidodendron z'asculare of Binney, whilst the former as clearly represents the Sigillaria vascularis of the same author, and the Sigillarian character of which is recognised by M. Renault. We thus have in one stem two branches, one of which, according to the views of the French savant, is a Crypto"On the Organisation of the Fossil Plants of the Coal-measures. Part X1. Paper read at the Royal Society by W. C. Williamson, F.R.S. Professor of Botany in the Owens Coliege, Manchester. Revised by the
Author. 
gamic Lycopod, and the other a Gymnospermous Sigillaria. The remarkable peculiarities characterising the central axis of these specimens make it absolutely certain that they all belong to one species of plant.

The typical Lepidodendron Harcourtii is then examined in a similar manner. In the details of its organisation it differs ma. terially from $L$. Selaginoides; nevertheless, as its growth progresses, it displays typically similar changes. It attains to much larger dimensions than the latter plant does before developing its exogenous zone, corresponding in this respect with the Arran plant. Its earlier changes are chiefly seen in the rapid development of the bast or prosenchymatous layer of the outer bark and in the increase in the size and number of the vessels constituting its vasculo-medullary cylinder or medullary sheath-the "étui medullaire" of Brongniart; but in more advanced specimens a cylindrical zone of centrifugally developed vascular wedges begins to make its appearance in a quasi-cambian zone of the cells of the inner bark, these cells being arranged in more or less regular radiating lines. In this state the rudimentary vascular zone corresponds very closely to what is seen in young stems and roots of Cycads.

The author shows that, contrary to the views of M. Renault, very marked changes take place in the development of the vascular bundles destined for the secondary branches of the plant. In the first instance, each of these is but a concavo. convex segment of the entire vasculo-medullary cylinder, whose detachment leaves a large gap in the continuity of that cylinder, which, however, soon becomes closed again by the convergence of the disconnected ends of the broken vascular circle. The concavo-convex detached segment undergoes a similar change. Its two extremities meet, and before it escapes from the outermost bark it has assumed the cylindrical form of its parent stem.

The rootlets of Stigmaria ficoides, now well known to belong alike to Lepidodendron and to Sigillaria, present some peculiarities of structure which are only found in the Lycopodiacex and the Ophioglossæ, amongst living plants.

The vascular bundle in the interior of each Stigmarian rootlet is inclosed within a very regularly circular cylinder, composed of the cells of the innermost bark ; but the position of the bundle in relation to the cylinder is always, unless accidentally disturbed, an eccentric one. This position has not escaped notice, but it was regarded as accidental; it now, however, proves to be a normal one. The bundle begins to appear in very young roots, as one or two very small vessels developed in close union with the innermost cells of one side of the cylinder within which it is located; newer and larger vessels are gradually added centripetally, until the bundle occupies a considerable portion of the area inclosed by the inner bark cylinder. The remaining space is usually empty, but occasionally specimens are found in which it is filled with small delicate cells that have escaped destruction. These represent what in the living Lycopods are liber-cells. The outer cortical layer of the root, composed of well-preserved and rather thick-walled cells, is usually separated from the inner cylinder by a similar lacuna; but in a few specimens the cells of this usually destroyed middle bark are retained in good preservation. 'They consist of very delicate thin-walled parenchyma, separated by a sharp line of demarcation equally from the innermost and outermost cortical cylinders. The number of the vessels in each of the vascular bundles given off from any one section of a Stigmarian root is found to vary but little, but they steadily increase, both in number and size, with the size and age of the root. Young specimens of Stigmarian roots are described, the smallest of which is not more than one-fifth of an inch in diameter, and the vascular bundles of its small rootlets consist each of from three to five minute vessels. In the largest rootlets from old roots they number about forty, most of the additional ones being of larger size; intermediate examples exhibit a regular gradation on all these points.

The only living plants which possess rootlets with this structure being Lycopodiaceæ and Ophioglossæ, and it being sufficiently clear that the Lepidodendra belong to the former and not to the latter order of cryptogams, the existence of this Lycopodiaceous feature in the rootlets of Sigillaria is another indication of the Lycopodaceous affinities of these plants.

Many of the Diploxyloid forms of the Lycopodiaceous stems of the coal-measures have an abundant development of spiral or barred cells in their numerous medullary rays. Amongst living plants this characteristic seems to be almost, if not wholly, confined to the Gymnosperms.
Two important additional observations have been made in reference to the structure of the curious strobilus, Calamostachys Binneyana. The exact mode of the attachment of its sporangia to the Equisetiform sporangiophores has been ascertained; but what is still more important, it has also been discovered that it is provided with both micro- and macro-spores-an additional indication of its probable Lycopodiaceous affinities, already suggested by other features of the fruit.

The recently discovered Fungi of the coal measures are investigated, especially the Pernosporites antiquiorum of $\mathrm{Mr}$. Worthington Smith. The author finds, in the specimens he has examined, including that described by Mr. Smith, no traces of septa in the hyphx or of zoospores in the Oogonia. He concludes that its affinities are probably with the Saprolegniæ, and not with the Pernosporea.

\section{UNIVERSITY AND EDUCATIONAL INTELLIGENCE}

THE Professorship of Zoology in the Royal College of Science, Dublin, is vacant by the resignation of Prof. Bridge. The salary is $200 \%$. a year, and at present the professor is only required to lecture during one term, commencing in February and ending in June.

The University Court of St. Andrews have elected Mr. Arthur Stanley Butler, B.A., of Exeter College, Oxford, to the Chair of Natural Philosophy in the United College, St. Andrews, in the room of Dr. William Swan, resigned.

THE Calendar of the University College of Wales for $1879-80$ shows that that institution is fairly well equipped in its various departments, science occupying a prominent place in its curriculum.

AT the end of the Legislative Session the French Chamber of Deputies voted a law establishing free primary education. It must go through the Upper House before becoming a definitive Law of the State.

\section{SCIENTIFIC SERIALS}

The American Naturalist, June,-A. E. Brown and J. D. Caton, the domestication of certain ruminants and aquatic birds. J. S. Lippincott, the critics of evolution (concluded).-C. E. Bessey, the supposed dimorphism of Lithospermum longiflorum (the large flowers appear from April to May, the cleistogamous flowers from then until the autumn frosts).-Dr. J. Leidy, on some aquatic worms of the family Naides (describes and figures Dero limosa, perhaps $=D$. digitata, Oken; Aulophorus vagus, this forms a tube of the statoblasts of a species of Plumatella, and Pristina flagellum).-W. H. Dall, American work in the department of recent mollusca during I 879 .

July.-G. Brown Goode, the use of agricultural fertilisers by the American Indians and the early English colonists (contains some interesting facts about fish manures). - C. S. Minot, sketch of comparative embryology (The Sponges).-O. B. Johnson, the birds of the Willamette Valley, Oregon,-J. F. James, a botanist in Southern California.-J. S. Kingsley, American carcinology in I879.-A. S. Packard, jun., the structure of the eye of trilobites, with figures ; concludes that the hard parts of the eye of the trilobites and of Limulus are throughout identical, while the nature of the soft parts of the former must ever remain problematical. There is good evidence that the retinal mass was like that of the king.crab; if so these forms as to their eye-structure will stand near each other and far apart from all other arthropods.

The Fournal of the Royal Microscopical Sociely, June, contains: Prof. Duncan, on a parasitic sponge of the order Calcarea (Plate ro), Mobiusispongia parasitica, growing within Carpenteria raphidodendron, from the reefs of Mauritius.-Dr. Cooke, on the genus Ravenelia (Plate II).-Dr. H. Gibbes, on double and treble staining. An excellent suggestion is incidentally made by Dr. Gibbes, that the covering glasses used by microscopists should be of a known thickness. We would even go further, and advise that a fixed scale of thickness might be adopted. Dr. Gibbes uses two thicknesses, 006 and $004 .-D r$. A. Grunow, on some new species of Nitzschia (Plates I2 and 13).James Smith, on the illumination of objects under the higher powers of the microscope.-The most useful record of current 